\title{
BUILDING COALITIONS: Understanding the Process
}

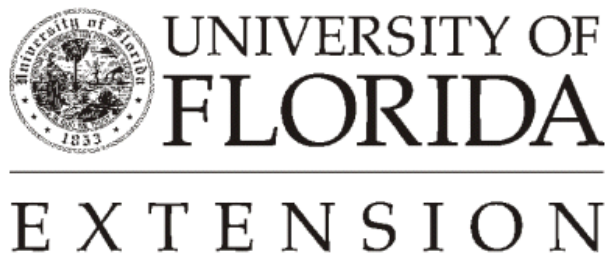

Institute of $\mathbf{F}_{\text {ood and }} \mathbf{A}_{\text {gricultural }} \mathbf{S}_{\text {ciences }}$ 
Tackling the problems of youth at risk must involve many people and organizations in communities. Developing coalitions of concerned individuals and groups can improve the efficiency and effectiveness of efforts by combining strengths and resources.

Once the coalition is formed, training in areas such as group dynamics, methods of problem solving, dealing with conflict and controversy, public policy process, issue analysis, and working with public officials may be beneficial. One task of a coalition might be to adapt, create or develop public policy.

Clearly, not all problems that affect you are public policy problems. Some may be readily resolved through the problem-solving process. The effectiveness of problem-solving can improve when the method is understood.

\section{The Problem Solving Method}

Define the Problem. Compare how things are now and the way you, would like them to be. How long has the problem existed? How frequently does it occur? Who is affected?

Determine the cause(s). This involves finding the cause of the gap between the present and the desired state.

Develop Alternative Approaches. List all possible solutions.

Assess the Consequences. Consider possible results of each alternative. Who is affected? Who pays?

Select a Solution. Choose one feasible alternative that is acceptable to the group.

Implement the Chosen Solution. Plan strategies for carrying out the plan. Most of the work is in this step.

Evaluate. Look back to review how things went. What was successful? What went wrong? Why?

These questions guide a coalition or individual through the policy analysis process.

\section{Selecting Issues For Analysis}

- $\quad$ Is there a decision to be made by government?

- Can the analysis significantly influence the adoption of various alternatives?

- Does the issue involve large costs or major consequences for services?

- Is there substantial room for improving program performance? 
- $\quad$ Is the public as a whole affected? How, directly or indirectly?

- Who else will the policy affect?

- What are the possible side effects ... immediate and long-run?

\section{Systematic Problem Solving}

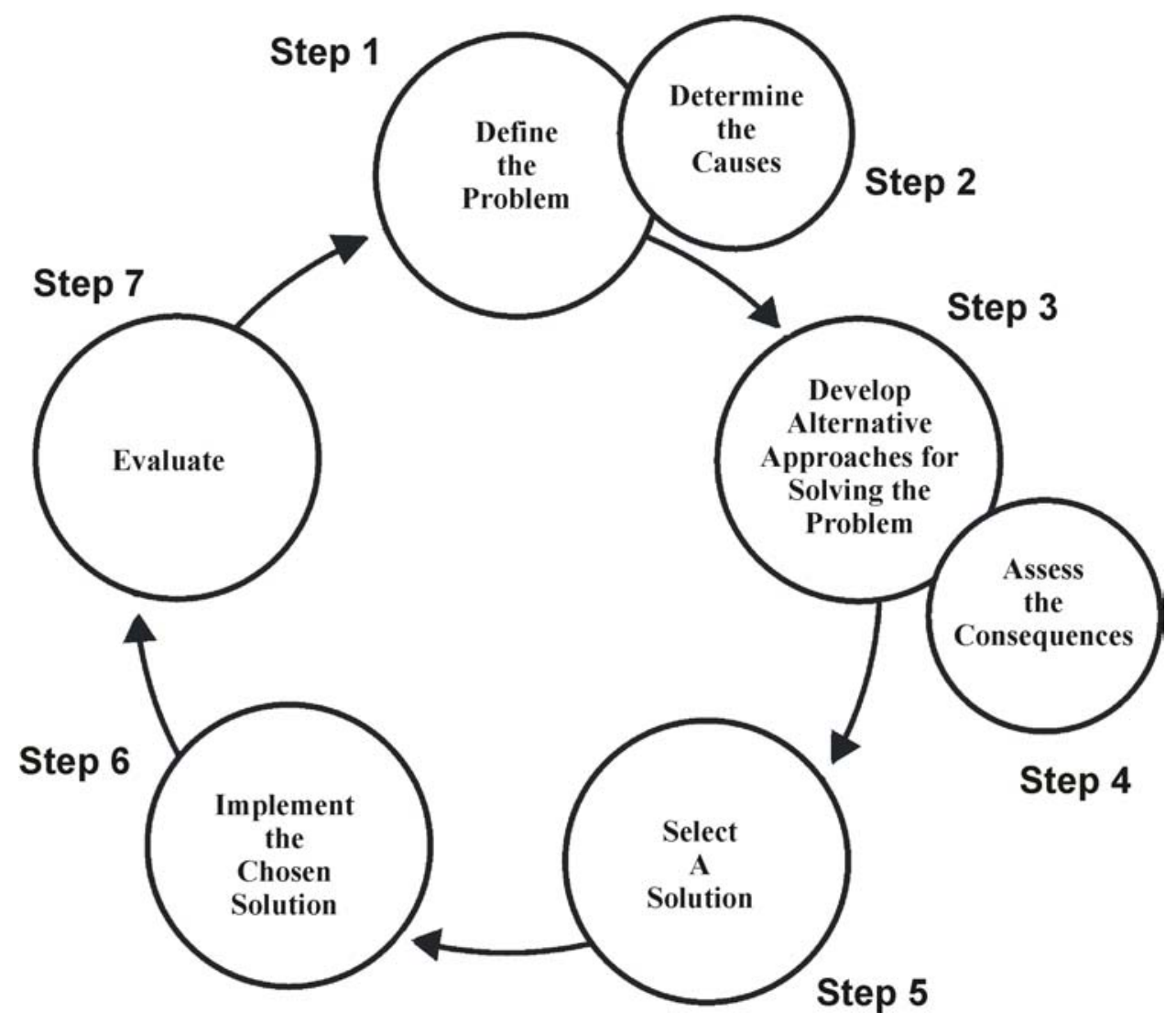

\section{Feasibility of Analysis}

- $\quad$ Can the problem be handled by program analysis?

- Is there time for the analysis to be done before key decisions must be made? 
- Are personnel and funds available to do the analysis?

- Does sufficient data exist to undertake the analysis?

- $\quad$ Can the needed data be gathered within the time available?

\section{Generic Critical Questions Regarding Policy Analysis}

- What are the purposes of the policy?

- Why should it be adopted?

- What is to be changed by it in both the immediate future and long term?

- How would you know if the policy had the intended impact?

- What would be accepted as evidence of its success?

- Who or what is the target of the policy?

- What would the likely consequences be if the new policy were implemented or another discontinued.

- What would be the reaction of citizens in the community?

- Who would complain?

- Who would be glad? Why?

\section{Criteria for Selecting Final Set of Measures}

Importance. Does the measure provide useful and important information on the program that justifies the difficulties in collecting, analyzing, or presenting the data?

Validity. Does the measure address the aspect of concern? Can changes in the value of the measure be clearly interpreted as desirable or undesirable? Can the changes be directly attributed to the program?

Uniqueness. Does the information provided by the measure duplicate or overlap with information provided by another measure?

Accuracy. Are the likely data sources sufficiently reliable or are there biases, exaggerations, omissions or errors that are likely to make the measure inaccurate or misleading? 
Timeliness. Can the data be analyzed in time for the decision?

Privacy and Confidentiality. Are there concerns for privacy or confidentiality that would prevent the analyst from obtaining the required information?

Costs of Data Collection. Can the resource or cost requirements for data -collection be met?

Completeness. Does the final set of measures cover the major aspects of the concern? 


\section{References}

Anderson, James E. Public Policy Making. 2d ed. 1979.

Harty , Harry P., Richard E. Winnie and Donald M. Fisk. Practical Program Evaluation For State And Local Governments. 2d ed. 1981.

Harty, Harry P., Louis Blair, Donald Fisk and Wayne Kimmel. Program Analysis For State And Local Government.1976.

Stebbins, Monine and Inge McNeese. One Step Away. Oregon Family Community Leadership HE-162L. 1983.

\section{Authors}

Ruth M. Conone, Assistant Director, Home Economics, Ohio Cooperative Extension Service, The Ohio State University.

Donna Brown, Program Coordinator, Home Economics, Ohio Cooperative Extension Service, The Ohio State University.

Russell Willis, Health Education Intern, The Ohio State University.

\section{(C)1992 The Ohio State University}

DEPS Ohio Cooperative Extension Service

This series on Coalition Building was developed by The Ohio Center For Action on Coalition Development for Family and High Risk Youth, Richard Clark, Ph.D., Director. It has been adapted for County Extension Faculty in Florida to facilitate work with local and regional organizations and groups such as non-profits, cooperatives, county extension associations, and others that might benefit from a plan for working together to achieve support for mutual goals.

This document is FY507, Part 15 of the 16 part series adapted for use in Florida by Elizabeth B. Bolton, Professor, Community Development and Lisa Guion, Assistant Professor, Program Planning and Evaluation; Department of Family, Youth and Community Sciences, Florida Cooperative Extension Service, Institute of Food and Agricultural Sciences, University of Florida, Gainesville, 32611-0310.

Reprinted with permission March, 1997. Revised April, 2002.

The Institute of Food and Agricultural Sciences is an equal opportunity/affirmative action employer authorized to provide research, educational information and other services only to individuals and institutions that function without regard to race, color, sex, age, handicap, or national origin. For information on obtaining other extension publications, contact your county Cooperative Extension Service office.

Florida Cooperative Extension Service/Institute of Food and Agricultural Sciences/University of Florida/Christine Taylor Waddill, Dean 